\title{
READERS
}

Journal of Management Info (JMI)

ISSN:2313-3376

www.readersinsight.net/jmi

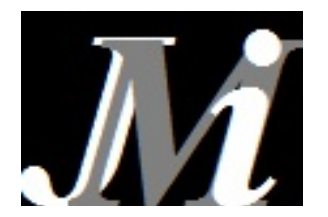

\section{Proposed model for effective training factors for competency of demolition operatives in Malaysia}

\author{
Hamed Ganjbakhsh ${ }^{1}$, Arham Bin Abdullah" ${ }^{2 *}$, Mohammadali Kazerooni Sadi ${ }^{3}$, Hamed Rahnama ${ }^{4}$ \\ 1,2,3,4 Department of Structure and Materials, Faculty of Civil Engineering, Universiti Teknologi Malaysia, Johor, 81310, Malaysia
}

* Corresponding author: arham@utm.my

\begin{abstract}
Recently, technology advancement influenced almost every field of life, bringing new tools and techniques to reduce human effort and risk involved. Similarly in the case of Demolition industry, technology changed the demolition procedures significantly. Most of the Countries are opting for new techniques for demolition operatives, which ultimately reduce the risk involved in the demolition process. Effective competency training modules have been adopted by many countries to develop the demolition operatives skills, so the health and safety measure could be increased while reducing impacts on the environment by the process. Malaysia has demolition procedures but unfortunately, the standards are not updated as compared to other countries. This enhances the element of the risk in demolition procedures. The current study has examined the current standard demolition procedures of developed countries to propose a training model for demolition practices in Malaysia. Demolition operatives are highly skilled and trained through competency based training programs to reduce the risk involved during the demolition procedures.
\end{abstract}

\section{ARTICLE INFORMATION}

Received: 25 April 2016

Revised: 25 May 2016

Accepted: 25 June 2016

DOI:

http://dx.doi.org//10.31580/jmi.v10i1.55

\section{Introduction}

Since the dawn of civilization, people have demolished structures to make room for new structures, to rehabilitate existing ones, and to create new edifices with materials taken from existing structures. Today, demolition became a barometer of economic activity. When demolition occurs, it is usually a sign of coming growth, expansion, or renewal (Diven and Taylor, 2006). In recent years, there has been an increased prevalence of building demolition projects throughout the world (Ghuraiz et al., 2011). However, some risks are involved in the demolition procedures if not handled efficiently. There is an increasing pressure on the demolition industry to apply standard procedures and insure safety and health measures in order to reduce the risks involved in the procedures. The traditional techniques of demolition bring problems to the environment, people and economy. Therefore alternative solutions are needed to meet the technical requirements and by applying standard procedures to mitigate the risk involved manage and control this major type of waste in an economically efficient and environmentally safe manner. Technological advancements somehow improved the demolition procedure efficiency and mitigate the risk involved (Kartam;AlMutairi; Al-Ghusain \& Al-Humoud, 2004), but the other factor related to the demolition procedural effectiveness which get little attention is competency of the demolition operatives, especially in the context of developing countries like Malaysia.

The developed countries like UK, Australia are applying advanced and standard techniques and procedures to mitigate the risk and insure health and safety management in order to control this major type of waste in an economically efficient and environmentally safe manner. These countries are using competency based training programmes to enhance their operative's competency. On the other hand these counties minimised the risk involved in the demolition operative competency through legislation (Haslam et al. 2003; Habilis, 2004) Although the effect of legislation is adverse in the case of these countries but the developing countries facing real challenge of not having up to date standards and training modules for the enhancing the competency of the demolition operatives. And the worst is theses counties do not legislate yet for the minimization of the risk, still growth in demolition industry is notable. Current study aims to identify factors affecting the competency of the demolition operatives in Malaysia and develop a competency based training module for the demolition operatives in the Malaysia. Moreover study highlights the role of standards and government legislation to enhance the competency of the demolition operatives.

\section{Understanding of the concept demolition}

Demolition is an activity in which the construction process is reversed; that is, the structure, or parts of the structure, are disassembled and removed. Sometimes it is misleading to use the word demolition to describe the industry today, since some structures are no longer demolished, but carefully dismantled or deconstructed so that more materials can be reused and recycled. The demolition of any type of structure is unique, due to the sheer number of parameters that govern the demolition process. Before selecting any type of demolition technique, the demolition contractor needs to consider a set of criteria and assess their relevance to the demolition work to be undertaken, in order to arrive at the most appropriate demolition technique (Abdullah, Anumba \& Durmisevic, 2003)

Construction and demolition (C\&D) waste refers to waste generated by the following: (1) construction, renovation, repair, and demolition of houses (Huang; Lin; Chang \& Lin, 2002; Jang \& Townsend, 2001)- 
(2) demolition of buildings and other civil engineering structures; (3) environmental disasters, such as earthquakes, hurricanes, tornadoes and flood water (Tansel, Whelan \& Barrera, 1994 ; Lauritzen, 1998). Demolition waste is often the most important component of the solid waste stream of developed countries representing between 20 and $30 \%$ and sometimes more than $50 \%$ of the total (Ekanayade \& Ofori, 2004).

Building demolition is one of the most common activities in the construction industry. Several demolition techniques are commonly used, including mechanical demolition, deconstruction and hybrid demolition. Although deconstruction has been advocated for its environmentally friendly approaches (Pun; Liu \& Langston, 2006). Accordingly, increasing building demolition activities are anticipated which accounts huge amounts of construction and demolition waste indicate that building demolition has become one of the most influential civil activities (Gao et al., 2001)

\section{Building demolition techniques}

Building demolition, as the final stage of a building's life cycle, can be traced back into ancient history since the first building was built. Until the 1950 s, buildings were mostly dismantled by hand at the end of their lives due to structural or functional obsolescence (Roodman and Lenssen, 1995; Gordon Engineering, 1997). Nowadays, following rapid development of construction technology, a number of demolition techniques are available. Especially, the use of mechanical equipment enables demolition techniques to adopt quicker and safer methods (Abdullah and Anumba, 2002). Generally speaking, three demolition techniques are used in building demolition, namely mechanical demolition, deconstruction and implosion. Among the three, implosion is usually used in demolition of high-rise buildings.

\section{Demolition and environmental concerns}

Demolition waste is a major part of industrial waste. In general, demolition waste is heterogeneous and consists to a large extent of building materials but includes even small amounts of hazardous substances. Since the early 1980s the processing of building rubble has become more and more common in most industrialised countries. After appropriate processing the major part of these materials meet the technical properties for reuse. Increasing emphasis is being placed on the environment-related properties due to composition and origin (Tränkler, Walker \& Dohmann,1996).

\section{Demolition phases}

Demolition process can be divided into three main phases as illustrated in Figure 1 of the sequential flow of activities involved. Principally, the sequence of demolition is carried out in reverse order to the construction process. According to Building and Construction Authority Singapore (2010), there are three principal phases involved in separating and sorting wastes that can be reuse and recycled with non-recyclable items. The first phase is part of building structures with higher concrete content being demolished (such as concrete parapet walls, etc). Then, to avoid contamination of clean concrete debris of building bearing structure, the second phase is stripping of delirious materials (such as bricks, tiles, etc). The last one is gradually demolishing the bearing and main structure by dismantling part of structures of similar materials to evade contamination of clean concrete debris and to allow separation of concrete debris from other demolition waste (Green and Gracious Guide, 2010).

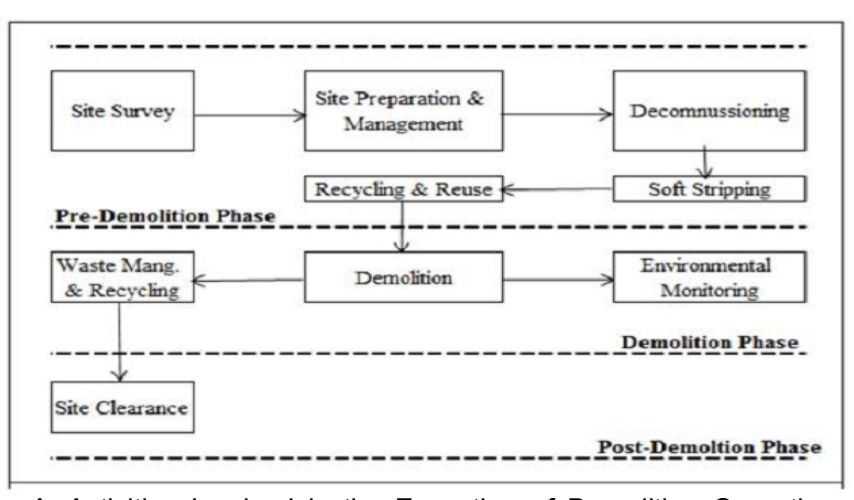

Fig. 1. Activities Involved in the Execution of Demolition Operations (Abdullah et al.2008)

\section{Conclusion}

Literature identified the four basic factors that influence the competency of the demolition operatives in the Malaysian demolition industry. A closer look at the factors and related items given a detailed practiced required for the demolition operatives. Risk management involves the practices of the tool handling, explosive and chemical handling procedures and damage control practices. Technical competency on the other hand required procedures to use the hand tools, towers and high reach crane operations, chemical and water jetting operations. Health and safety requirements related to the self-safety, workers safety, site safety and public safety procedures and environmental concerns related to the dust control, noise control and other waste management.

Above mentioned practices can lead to a framework for the affective training for the demolition operatives in the Malaysian Industry. Figure 2 proposed a framework for the training and also highlighted the basic required factors in each factor related the competency of the demolition operatives in Malaysia.

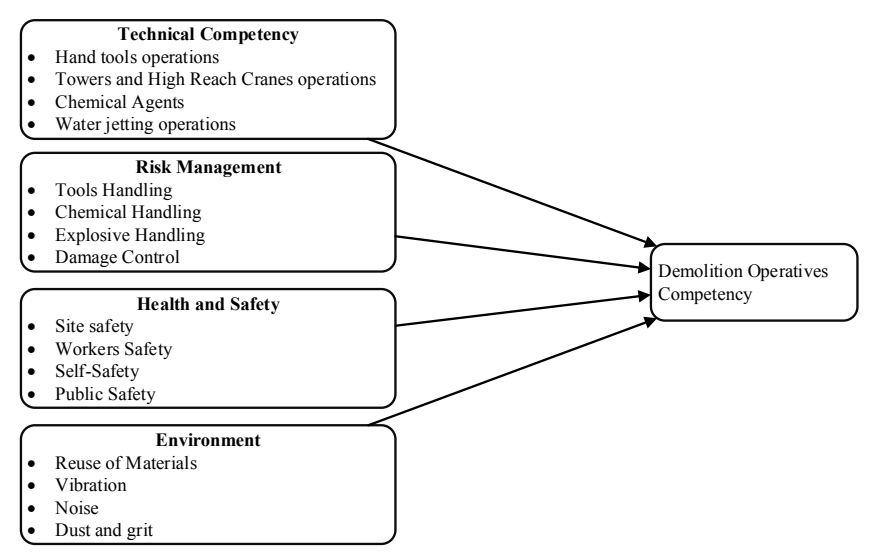

Fig. 2. Proposed Framework

\section{References}

Abdullah, A., Anumba, C., \& Durmisevic, E. (2003). Decision Tools for Demolition Techniques Selection. In Proceedings (pp. 55-72).

Atkinson, R. (2004) The evidence on the impact of gentrification: new lessons for the urban renaissance. European Journal of Housing Policy, 4(1), $107-31$.

Ekanayade, L.L and Ofori, G (2004). Building waste assessment score: designbased tool. Build. Environ., 39, 851-861

Gao, W., Ariyama, T., Ojima, T. and Meier, A. (2001) Energy impacts of recycling disassembly material in residential buildings. Energy and Buildings, 33(6), 553-62.

Gordon Engineering (1997) Demolition Energy Analysis of Office Building Structural Systems, Athena Sustainable Materials Institute, Ottawa, Canada 
Huang, W.L., Lin, D.H., Chang, N.B. and Lin, L.S (2002). Recycling of construction and demolition waste via a mechanical sorting process Resour. Conserv. Recy., 37, 23- 37

Jang, Y.C. and Townsend, T.G (2001). Occurrence of organic pollutants in recovered soil fines from construction and demolition waste. Waste Manage., 21, 703-715

Kartam, N., Al-Mutairi, N., Al-Ghusain, I., \& Al-Humoud, J. (2004). Environmental management of construction and demolition waste in Kuwait.Waste Management, 24(10), 1049-1059.

Lauritzen, E.K (1998). Emergy construction waste management. Safety Sci., $30,45-53$
Pun, S. K., Liu, C., \& Langston, C. (2006). Case study of demolition costs of residential buildings. Construction management and economics, 24(9), 967-976.

Roodman, D. and Lenssen, N. (1995) A Building Revolution: How Ecology and Health Concerns are Transforming Construction, Worldwatch Institute, Washington, USA.

Tränkler, J. O., Walker, I., \& Dohmann, M. (1996). Environmental impact of demolition waste - an overview on 10 years of research and experience. Waste management, 16(1), 21-26.

Tansel, B., Whelan, M. and Barrera, S (1994). Building performance and structural waste generation by Hurricane Andrew. Int. J. Housing Sci. Appl., 18, 69-77. 